
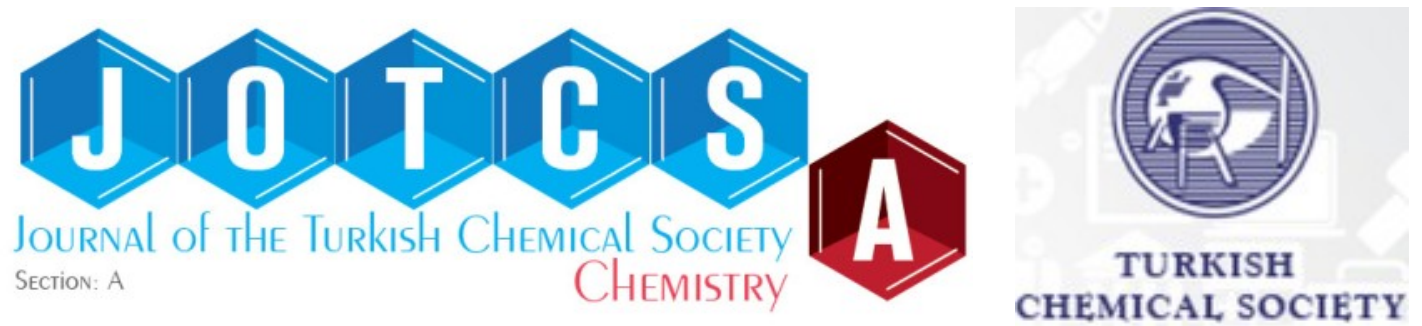

\title{
Synthesis and Spectroscopic Characterization of Protic Tris(2- Hydroxyethyl)-Ammonium Ionic Liquids
}

\author{
Hüseyin AKBAŞ ${ }^{1, *}$ \\ ${ }^{1}$ Department of Chemistry, Tokat Gaziosmanpaşa University, 60250, Tokat, Turkey
}

Abstract: Protic ionic liquids (PILs) having tris(2-hydroxyethyl)ammonium (or triethanolammonium) as cations and methacrylate, dihydrogenborate, formate, and acetate as anions have been synthesized through stoichiometric neutralization reaction. PILs have been characterized by elemental analyses, FTIR, ${ }^{1} \mathrm{H}$ and ${ }^{13} \mathrm{C}$ NMR spectroscopic methods. The viscosity of PIL4 was measured using a cone-and-plate viscometer at ambient temperature. The viscosity value indicates that the fluidity of PIL4 is $829 \mathrm{cP}$ (the viscosity of water is $0.7977 \mathrm{cP}$ at $30^{\circ} \mathrm{C}$ ).

Keywords: Protic ionic liquids, Spectroscopy, Synthesis, Triethanolammonium salts, Viscosity.

Submitted: August 28, 2019. Accepted: October 07, 2019.

Cite this:

DOI: https://doi.org/10.18596/jotcsa.612396.

*Corresponding author. E-mail: huseyin.akbas@gop.edu.tr.

\section{INTRODUCTION}

In general, ionic liquids (ILs) are liquid at temperatures below $100{ }^{\circ} \mathrm{C}$ and those liquids can remain fluid in a wide temperature range (1). ILs have attracted intense interest in both academia and industry in recent years due to their impressive properties such as low volatility, high dissolution capacity, large electrochemical window, and high thermal and electrical conductivity (2-4). One of the most important properties of ILs is their environmentally friendly and non-hazardous nature due to negligible vapor pressures. Thus, ILs have recently been of great interest as green chemicals rather than conventional solvents (5).

PILs are obtained by proton transfer between a Brønsted acid and a Brønsted base (6). An equimolar amount of acid and base react together in a uniform or aqueous solution. In general, the rest of ILs can be classified as aprotic ILs (AILs), but there are some subclasses similar to PILs such as Brønsted acidic ILs, which are typically functionalized to have a proton present on the anion. PILs have many applications as lubricants $(7,8)$, biologically active materials $(9,10)$, electrolytes (11-13), catalysts (14 15), etc.

Hydroxylammonium-based PILs have hydrogen bond donor properties that significantly increase their applications. Hydroxylammonium IL has been used to dissolve many insoluble polymers such as zein (an industrially important natural polymer), polyaniline and polypyrrole (16). The effect of the hydroxyl group on the dissolution with polar solvents in this type of IL was disclosed by determining the solvatochromic parameter (17). Nowadays, aqueous monoethanolamine has been used for the removal of $\mathrm{CO}_{2}$ from natural gas in industrial processes due to serious environmental concerns about volatility, recovery and abrasiveness (18). Yuan et al. synthesized a series of hydroxylammonium ILs and determined the solubility of $\mathrm{SO}_{2}$ at atmospheric pressure (19). Garaev et al. found that hydroxylammoniumbased ILs with carboxylate anion are highly biodegradable and practically non-toxic (20). 
Ahfad-Hosseini et al. developed a new method for the synthesis of celecoxib (a selective COX-2 inhibitor) with high yield and least environmental hazard using tris-(2-hydroxyethyl)ammonium acetate (II) as IL and evaluated the effect of IL concentration and reaction temperatures on the yield of celecoxib production (21). Furthermore, the physicochemical properties of hydroxylammonium-based ILs such as glass transition temperature, density, conductivity, sound velocity, viscosity and decomposition temperature at different temperatures have been studied intensively (22-25).

Herein, the PILs consisting of tris(2hydroxyethyl)ammonium cation and anions of different inorganic or carboxylic acids have been obtained, and these are tris(2hydroxyethyl)ammonium methacrylate (PIL1), tris(2-hydroxyethyl)ammonium dihydrogenborate (PIL2), tris(2-hydroxyethyl)ammonium formate (PIL3) and tris(2-hydroxyethyl)ammonium acetate (PIL4) (Scheme 1). The structure of the synthesized PILs was determined by elemental analysis, FTIR, ${ }^{1} \mathrm{H}$ and ${ }^{13} \mathrm{C}$ NMR techniques. The viscosity has been measured at atmospheric pressure with ambient temperature.

\section{EXPERIMENTAL}

\section{Material and Methods}

Triethanolamine, methacrylic acid, boric acid, formic acid, and acetic acid were purchased from commercial sources and used without further purification. ${ }^{1} \mathrm{H}$ - and ${ }^{13} \mathrm{C}$-NMR spectra of the PILs were measured using AC Bruker $400 \mathrm{MHz}$ NMR spectrometer in Methanol- $\mathrm{d}_{4}$ and $\mathrm{D}_{2} \mathrm{O}$ at ambient temperature. FT-IR spectra were recorded on a Jasco FT-IR 4700 spectrometer in the range of 400-4000 $\mathrm{cm}^{-1}$. Elemental analyses were recorded on a Elementar Vario Micro Cube elemental analyzer. The viscosity of PIL4 was measured using a Brookfield DV2TRVCP Viscometer. The cone and plate method was used where the sample $(0.5 \mathrm{~mL})$ was placed between a $2 \mathrm{~cm}$ cone and a flat plate. The cone was made to rotate and the viscosity of the sample was measured.<smiles>CC(=O)OC(=O)C(C)=CC(=O)O</smiles>

Scheme 1. The scheme represents the PILs.

\section{General procedure for the synthesis of PILs 1-4}

The PILs were synthesized according to the previous literature (26). A mixture of triethanolamine $(5.00 \mathrm{~g}, 33.51 \mathrm{mmol})$ and methacrylic acid $(2.89 \mathrm{~g}, 33.51 \mathrm{mmol})$, boric acid $(2.07 \mathrm{~g}, 33.51 \mathrm{mmol})$, formic acid $(1.54 \mathrm{~g}, 33.51$ mmol) or acetic acid $(2.01 \mathrm{~g}, 33.51 \mathrm{mmol})$ is prepared in 1:1 molar ratio. Triethanolamine is placed in a two-necked $100 \mathrm{~mL}$ round-bottomed flask, which is fitted with a dropping funnel, and connected to a condenser. Methacrylic acid, boric acid, formic acid or acetic acid is placed in the dropping funnel, and added the acid dropwise to the diethylenetriamine in the flask. The reaction 
is vigorous and the rate is controlled by regulating the addition of acid. The reaction should be complete in about $24 \mathrm{~h}$. The PILs thus prepared was kept in a vacuum oven at $80{ }^{\circ} \mathrm{C}$ for 48 hours to remove excess moisture formed during the reaction. The dried solvent was sealed with laboratory parafilm to prevent any moisture contamination.

\section{Synthesis of PIL1}

Anal. Calc. for $\mathrm{C}_{6} \mathrm{H}_{16} \mathrm{NO}_{3}{ }^{+}\left(\mathrm{C}_{4} \mathrm{H}_{5} \mathrm{O}_{2}{ }^{-}\right)$(\%): C, 51.05; $\mathrm{H}, 9.00 ; \mathrm{N}, 5.95$ Found (\%): C, 49.96; H, 8.98; $\mathrm{N}$, 5.92. FTIR $\left(\mathrm{cm}^{-1}\right)$ : เ์ $3232(\mathrm{O}-\mathrm{H}), 2922(\mathrm{C}-\mathrm{H}$ aliph.asym.), 2876 (C-H aliph.sym.), 1644 $(\mathrm{C}=\mathrm{C}), 1551,1445\left(\mathrm{COO}^{-}\right), 1062(\mathrm{C}-\mathrm{N}) .{ }^{1} \mathrm{H}$ NMR $\left(\mathrm{D}_{2} \mathrm{O}, \mathrm{ppm}\right.$, numberings of protons are given in Scheme 1): $3.91\left(\mathrm{t}, 6 \mathrm{H},{ }^{3} \mathrm{~J}_{\mathrm{HH}}=4.7 \mathrm{~Hz}, \boldsymbol{H}_{\mathbf{1}}\right), 3.38$ $\left(\mathrm{t}, 6 \mathrm{H},{ }^{3} \mathrm{~J}_{\mathrm{HH}}=4.7 \mathrm{~Hz}, \boldsymbol{H}_{2}\right), 5.62 ; 5.31\left(\mathrm{~d}, 2 \mathrm{H},{ }^{2} \mathrm{~J}_{\mathrm{HH}}=\right.$ $\left.1.0 \mathrm{~Hz}, \boldsymbol{H}_{4}\right), 1.84\left(\mathrm{~s}, 3 \mathrm{H}, \mathrm{CH}_{3}\right), 4.69-8.04(\mathrm{~m}, 4 \mathrm{H}$, $\left.\mathrm{HN}^{+}, \mathrm{OH}\right) .{ }^{13} \mathrm{C} N M R\left(\mathrm{D}_{2} \mathrm{O}, \mathrm{ppm}\right.$, numberings of carbons are given in Scheme 1): $55.55\left(\boldsymbol{C}_{\mathbf{1}}\right)$, $55.36\left(\boldsymbol{C}_{2}\right), 177.38(\boldsymbol{C}=0), 142.42\left(\boldsymbol{C}_{3}\right), 120.24$ $\left(\mathrm{CH}_{3}\right), 18.92\left(\boldsymbol{C}_{4}\right)$.

\section{Synthesis of PIL2}

Anal. Calc. for $\mathrm{C}_{6} \mathrm{H}_{16} \mathrm{NO}_{3}{ }^{+}\left(\mathrm{BH}_{2} \mathrm{O}_{3}{ }^{-}\right)$(\%): C, 34.15; $\mathrm{H}, 8.60 ; \mathrm{N}, 5.12$ Found (\%): C, 34.23; $\mathrm{H}, 8.41$; $\mathrm{N}, 5.18$. FTIR $\left(\mathrm{cm}^{-1}\right)$ : ํํ $3270(\mathrm{O}-\mathrm{H}), 2951(\mathrm{C}-\mathrm{H}$ aliph.asym.), 2877 (C-H aliph.sym.), 1369 (B-O), 1065 (C-N). ${ }^{1} \mathrm{H}$ NMR (methanol- $\mathrm{d}_{4}$, ppm, numberings of protons are given in Scheme 1): $3.88\left(\mathrm{t}, 6 \mathrm{H},{ }^{3} \mathrm{~J}_{\mathrm{HH}}=5.8 \mathrm{~Hz}, \boldsymbol{H}_{\mathbf{1}}\right), 3.21\left(\mathrm{t}, 6 \mathrm{H},{ }^{3} \mathrm{~J}_{\mathrm{HH}}=\right.$ $\left.5.8 \mathrm{~Hz}, \boldsymbol{H}_{2}\right), 3.61-8.06\left(\mathrm{~m}, 6 \mathrm{H}, \mathrm{HN}^{+}, \mathrm{OH}\right) .{ }^{13} \mathrm{C}$ NMR (methanol- $\mathrm{d}_{4}, \mathrm{ppm}$, numberings of carbons are given in Scheme 1): $63.01\left(\boldsymbol{C}_{\mathbf{1}}\right), 59.70\left(\boldsymbol{C}_{\mathbf{2}}\right)$.

\section{Synthesis of PIL3}

Anal. Calc. for $\mathrm{C}_{6} \mathrm{H}_{16} \mathrm{NO}_{3}{ }^{+}\left(\mathrm{CHO}_{2}{ }^{-}\right)$(\%): C, 43.07; $\mathrm{H}, 8.78$; N, 7.18 Found (\%): C, 43.38; H, 8.96; $\mathrm{N}, 7.22$. FTIR $\left(\mathrm{cm}^{-1}\right)$ : เ $3239(\mathrm{O}-\mathrm{H}), 2935(\mathrm{C}-\mathrm{H}$ aliph.asym.), 2876 (C-H aliph.sym.), 1588, 1439 (COO), 1060 (C-N). ${ }^{1} \mathrm{H}$ NMR (methanol-d 4 , ppm, numberings of protons are given in Scheme 1): $3.77\left(\mathrm{t}, 6 \mathrm{H},{ }^{3} \mathrm{~J}_{\mathrm{HH}}=5.3 \mathrm{~Hz}, \boldsymbol{H}_{\mathbf{1}}\right), 3.24\left(\mathrm{t}, 4 \mathrm{H},{ }^{3} \mathrm{~J}_{\mathrm{HH}}=\right.$ $\left.5.3 \mathrm{~Hz}, \boldsymbol{H}_{2}\right), 8.43(\mathrm{~s}, 1 \mathrm{H},-\boldsymbol{H}), 4.77-7.99(\mathrm{~m}, 4 \mathrm{H}$, $\mathrm{HN}^{+}, \mathrm{OH}$ ). ${ }^{13} \mathrm{C}$ NMR (methanol-d $\mathrm{d}_{4} \mathrm{ppm}$, numberings of carbons are given in Scheme 1 ): $57.35\left(\boldsymbol{C}_{\mathbf{1}}\right), 57.16\left(\boldsymbol{C}_{\mathbf{2}}\right), 169.95(\boldsymbol{C}=0)$.

\section{Synthesis of PIL4}

Anal. Calc. for $\mathrm{C}_{6} \mathrm{H}_{16} \mathrm{NO}_{3}{ }^{+}\left(\mathrm{C}_{2} \mathrm{H}_{3} \mathrm{O}_{2}^{-}\right)$(\%): C, 45.92; $\mathrm{H}, 9.15$; N, 6.69 Found (\%): C, 46.13; H, 8.91; $\mathrm{N}, 6.82$. FTIR $\left(\mathrm{cm}^{-1}\right)$ : ํํ $3187(\mathrm{O}-\mathrm{H}), 2924(\mathrm{C}-\mathrm{H}$ aliph.asym.), 2864 (C-H aliph.sym.), 1563, 1397 $\left(\mathrm{COO}^{-}\right), 1062(\mathrm{C}-\mathrm{N}) .{ }^{1} \mathrm{H}$ NMR (methanol-d $\mathrm{d}_{4}, \mathrm{ppm}$, numberings of protons are given in Scheme 1): $3.70\left(\mathrm{t}, 6 \mathrm{H},{ }^{3} \mathrm{~J}_{\mathrm{HH}}=5.4 \mathrm{~Hz}, \boldsymbol{H}_{\mathbf{1}}\right), 3.05\left(\mathrm{t}, 6 \mathrm{H},{ }^{3} \mathrm{~J}_{\mathrm{HH}}=\right.$ $\left.5.4 \mathrm{~Hz}, \boldsymbol{H}_{2}\right), 1.83\left(\mathrm{~s}, 3 \mathrm{H},-\mathrm{CH}_{3}\right), 4.77-7.97(\mathrm{~m}$, $\left.4 \mathrm{H}, \mathrm{HN}^{+}, \mathrm{OH}\right) .{ }^{13} \mathrm{C}$ NMR (methanol- $\mathrm{d}_{4}, \mathrm{ppm}$, numberings of carbons are given in Scheme 1 ): $58.31\left(\boldsymbol{C}_{1}\right), \quad 57.49\left(\boldsymbol{C}_{2}\right), 23.14\left(\boldsymbol{C H}_{3}\right), 178.80$ $(\boldsymbol{C}=0)$.

\section{RESULTS AND DISCUSSION}

Tris(2-hydroxyethyl)ammonium cation based PILs were synthesized by proton transfer between an equimolar amount of triethanolamine, and different acids such as methacrylic acid, boric acid, formic acid or acetic acid (Scheme 1). The triethanolamine and various acids have been selected based on their structural properties and availability. At room temperature, PIL4 is liquid, while PIL1-3 are quasi-solid state. All the PILs were soluble in polar protic solvents such as water, methanol, and ethanol. There are publications in which the triethanolamine salt (PIL3 and PIL4) containing formic and acetic acid is indicated $(20,21,27)$. However, only ${ }^{1} \mathrm{H}$ NMR (using DMSO as a solvent) and FT-IR (using a $\mathrm{NaCl}$ disk) spectroscopic techniques were used for structural characterization. A structural study based on NMR $\left({ }^{1} \mathrm{H}\right.$ - and ${ }^{13} \mathrm{C}-$ ) spectroscopy of the prepared PILs was subsequently performed in concordance with FT-IR spectra and elemental analysis. Thus, these studies have confirmed the presence of protonated amine.

The chemical shifts, multiplicities and coupling constants of all PILs were determined by interpreting the ${ }^{1} \mathrm{H}$ and ${ }^{13} \mathrm{C}$ NMR signals (Supplementary Material, Figures S1-8), and are presented in the "Experimental Section". The three PILs could easily be dissolved in methanol$\mathrm{d}_{4}$, except PIL1. For the triethanolammonium cation, the resonance signals of the $\mathrm{CH}_{2}$ group protons (3.91-3.70 ppm for $\boldsymbol{H}_{1}$ and 3.38-3.05 ppm for $\boldsymbol{H}_{2}$ ) in the ${ }^{1} \mathrm{H}$ NMR spectra of PILs are downfield-shifted compared to the original triethanolamine (3.46 ppm for $\boldsymbol{H}_{\mathbf{1}}$ and $2.57 \mathrm{ppm}$ for $\boldsymbol{H}_{2}$ ) (28). The chemical shift does not exceed $0.8 \mathrm{ppm}$. The average coupling constant, ${ }^{3} \mathrm{~J}_{\mathrm{HH}}$, is $5.3 \mathrm{~Hz}$. Both the $\mathrm{OH}$ and the $\mathrm{NH}$ resonances are relatively broad at 3.61-4.77 ppm and 7.97-8.06 ppm, respectively. Further, the carboxylic acid proton (-COOH) at about 8-12 ppm (29) was not observed in the ${ }^{1} \mathrm{H}$ NMR spectra of the PIL1, PIL3 and PIL4. This may be indicative of the formation of PILs. ${ }^{13} \mathrm{C}$ NMR chemical shifts of the triethanolammonium cation in the spectra of the studied PILs are in the range of 63.01-55.55 ppm for the neighboring the oxygen atom $\left(\boldsymbol{C}_{\boldsymbol{1}}\right)$, while those of the protons adjacent to the nitrogen atom $\left(\boldsymbol{C}_{\mathbf{2}}\right)$ are in the range of $59.70-55.36 \mathrm{ppm}$. On the other hand, the carbonyl carbon atoms $(\boldsymbol{C}=0)$ of the PIL1, PIL3 and PIL4 were 
observed at $177.38,169.95$ and 178.80 ppm, respectively.

In tris(2-hydroxyethyl)-ammonium based PILs, the proton of the acid is located on the onium nitrogen atom $\left(\mathrm{N}^{+} \mathrm{H}\right)$ in the cation and forms trifurcate hydrogen bonds with three hydroxyethyl groups resulting in the formation of the tricyclic protatran cation $(30,31)$. Therefore, these PILs are known as protatranes (Figure 1).

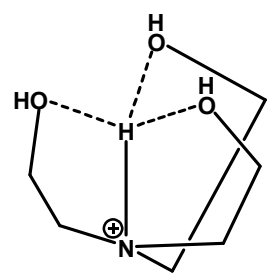

Figure 1. The structure of the tris(2-

hydroxyethyl)-ammonium cation (protatrane).

The results of the FT-IR analyses were very similar for all of the PILs. In the absorption IR spectra of the obtained PILs, a broad characteristic ammonium band of $\mathrm{v}\left(\mathrm{N}^{+} \mathrm{H}\right)$ was observed in the range of $2400-3000 \mathrm{~cm}^{-1}$ (Figure S9). In the FT-IR spectrum of triethanolamine, the strong band at $3303 \mathrm{~cm}^{-1}$ corresponds to the stretching vibrations of the $\mathrm{OH}$ groups involved in intramolecular hydrogen bonds. The wide band of $\mathrm{v}(\mathrm{OH})$ resulting from the high symmetry of the molecules of the PILs was found at about 3232 $\mathrm{cm}^{-1}$. This band is due to the vibrations of the three hydroxy groups of the triethanolammonium cation in which oxygen atoms form intramolecular hydrogen bonds with the $\mathrm{N}^{+} \mathrm{H}$ hydrogen atom (Figure 1). A higher strength hydrogen bond formed by the $\mathrm{OH}$ groups of the protatant cation with the carboxylic group of the acid anion results in $\mathrm{v}(\mathrm{OH})$ bands at low frequencies $\left(\sim 3153 \mathrm{~cm}^{-1}\right)(32)$. This explanation disagrees with the FT-IR results of the PILs, the spectrum of which does not have this band. Protatrane methylene $\mathrm{CH}_{2}$ vibrations correspond to the bands at 2951-2864 $\mathrm{cm}^{-1}$. The PILs show two strong absorption bands between 1563-1551 and $1445-1397 \mathrm{~cm}^{-1}$, which are assigned to the asymmetric and symmetric stretching vibrations of the carboxylate ion, $\mathrm{v}\left(\mathrm{COO}^{-}\right)$, respectively, indicating clearly the PIL formation. At the same time, it was known that the degree and nature of interaction between the cation and anion in proptatrane is reflected in the frequencies of symmetric and asymmetric vibrations $\mathrm{v}\left(\mathrm{COO}^{-}\right)$ $(33,34)$. The difference between these values $(\Delta v)$ is used as a criterion of the structure of the molecule. The value of $\Delta v>200 \mathrm{~cm}^{-1}$ points to a significant asymmetry of the carboxylic group, while the value of $\Delta v<200 \mathrm{~cm}^{-1}$ is indicative of its approximate symmetry (35). The molecule of PIL1 is characterized by the vibration bands of the carboxylate anion at $1551\left[\mathrm{~V}_{\text {as }}\left(\mathrm{COO}^{-}\right)\right]$and $1445 \mathrm{~cm}^{-1}\left[\mathrm{v}_{\mathrm{s}}\left(\mathrm{COO}^{-}\right)\right]$. The value of $\Delta \mathrm{v}$ equal to $106 \mathrm{~cm}^{-1}$ points to a significant symmetry of the carboxylic group. It can be assumed that other PIL3 $\left(149 \mathrm{~cm}^{-1}\right)$ and PIL4 $\left(166 \mathrm{~cm}^{-1}\right)$ with $\Delta v<$ $200 \mathrm{~cm}^{-1}$ have the structure close to that of PIL1.

The viscosity of the PIL4 which was liquid at ambient temperature was measured. Considering the fluidity of PIL4, CP52 type spindle was used to measure the viscosity of this PIL, and viscosity value was given in Table 1 . Most PILs are viscous liquids, the viscosities being comparable to and greater than the viscosity of water (water's viscosity is $0.7977 \mathrm{cP}$ at $30{ }^{\circ} \mathrm{C}$ ) (36). Also, the viscosity of the PIL4 is higher compared to the initial triethanolamine $\left(404 \mathrm{cP}\right.$ at $\left.30^{\circ} \mathrm{C}\right)(37)$.

Table 1. Viscosity data of PIL4.

\begin{tabular}{llllll}
\hline Code & Viscosity (cP) & Temperature $\left({ }^{\circ} \mathbf{C}\right)$ & Speed (RPM) & Torque (\%) & Spindle \\
\hline PIL4 & 829 & 29 & 60 & 50.1 & CP-52 \\
\hline
\end{tabular}

\section{CONCLUSION}

Four triethanolammonium-based PILs which belongs to the class of protic alkanolammonium ionic liquids, have been synthesized by proton transfer reaction from carboxylic and inorganic acids to triethanolamine. These PILs show good solubility in polar solvents (water, alcohols, etc.). The PILs have been established by elemental analysis and ${ }^{1} \mathrm{H},{ }^{13} \mathrm{C}$ NMR, FT-IR spectroscopic methods. It is shown that the obtained spectral characteristics confirm salt formation for all the studied compounds. The structure of PILs depends on the type and strength of hydrogen bonds between the triethanolammonium cation (protatrane) and carboxylate anion, which affects the frequencies of stretching vibrations of $\mathrm{OH}^{-}$ and $\mathrm{COO}^{-}$groups.

\section{ACKNOWLEDMENTS}

The author acknowledges to Professor Ahmet Karadağ for his helpful comments.

\section{REFERENCES}

1. Wasserscheid P, Keim W. Ionic liquidsnew "solutions" for transition metal 
catalysis. Angew. Chem. Int. Ed. 2000;39:3772-89.

2. Chhotaray PK, Gardas RL. Thermophysical properties of ammonium and hydroxylammonium protic ionic liquids. J. Chem. Thermodynamics 2014;72:117-24.

3. Marcinkowski $\quad$, Pena-Pereira F, Kloskowski A, Namiesnik J. Opportunities and shortcomings of ionic liquids in single-drop microextraction. Trends in Analyt. Chem. 2015;72:153-68.

4. Oliveria MVS, Vidal BT, Melo CM, de Miranda RCM, Soares CMF, Coutinho JAP, Ventura SPM, Mattedi S, Lima AS. (Eco) toxicity and biodegradability of protic ionic liquids. Chemosphere 2016;147:460-6.

5. Earle MJ, Seddon KR. Ionic liquids. Green solvents for the future. Pure Appl. Chem. $2000 ; 72: 1391-98$.

6. Austen CA, Ansari $Y$, Zhao Z. Ionic liquids: past, present and future. Faraday Discuss. 2012;154:9-27.

7. Zhao Q, Zhao G, Zhang M, Wang X, Liu $W$. Tribological behavior of protic ionic liquids with dodecylamine salts of dialkyldithiocarbamate as additives in lithium complex grease. Tribol. Lett. 2012;48:133-44.

8. Espinosa $T$, Sanes J, Jiménez $A$, Bermúdez $M$. Protic ammonium carboxylate ionic liquid lubricants of OFHC copper. Wear 2013;303:495-509.

9. Akbaş $H$, Okumuş $A$, Karadağ $A$, Kılıç $Z$, Hökelek T, Koç LY, Açık L, Aydın B, Türk $M$. Structural and thermal characterizations, antimicrobial and cytotoxic activities, and in vitro DNA binding of the phosphazenium salts. J. Therm. Anal. Calorim. 2016;123:162741.

10. Akbaş $H$, Karadağ $A$, Aydın A, Destegül A, Kılıç Z. Synthesis, structural and thermal properties of the hexapyrrolidinocyclotriphosphazenesbased protic molten salts: Antiproliferative effects against HT29, HeLa, and C6 cancer cell lines. J. Mol. Liq. 2017;230: 482-95.
11. Nakamotoa $H$, Watanabe $M$. Brønsted acid-base ionic liquids for fuel cell electrolytes. Chem. Commun. 2007;2539-41.

12. Yasuda T, Watanabe M. Protic ionic liquids: fuel cell applications. MRS Bulletin 2013;38:560-66.

13. Vogl T, Menne $S$, Kühnel $R$, Balducci $A$. The beneficial effect of protic ionic liquids on the lithium environment in electrolytes for battery applications. J. Mater. Chem. A 2014;2:8258-65.

14. Akbari J, Heydari A, Ma'mani L, Hosseini $\mathrm{SH}$. Protic ionic liquid [TMG][Ac] as an efficient, homogeneous and recyclable catalyst for Boc protection of amines. Chimie C.R. 2010;13:544-47.

15. Xiao L, Su D, Yue C, Wu W. Protic ionic liquids: A highly efficient catalyst for synthesis of cyclic carbonate from carbon dioxide and epoxides. J. $\mathrm{CO}_{2}$ Utilization 2014;6:1-6.

16. Choi HM, Kwon I. Dissolution of zein using protic ionic liquids: $\mathrm{N}-(2-$ Hydroxyethyl) ammonium formate and $\mathrm{N}$-(2-hydroxyethyl) ammonium acetate. Ind. Eng. Chem. Res. 2011;50:2452-54.

17. Salari $H$, Harifi-Mood $A R$, Elahifard $M R$, Gholami MR. Solvatochromic probes absorbance behavior in mixtures of 2hydroxy ethylammonium formate with methanol, ethylene glycol and glycerol. J. Sol. Chem. 2010;39:1509-19.

18. Bara JE, Camper DE, Gin DL, Noble RD. Room-temperature ionic liquids and composite materials: platform technologies for $\mathrm{CO}_{2}$ capture. Acc. Chem. Res. 2010;43:152-59.

19. Yuan X, Zhang S, Liu J, Lu X. Solubilities of $\mathrm{CO}_{2}$ in hydroxyl ammonium ionic liquids at elevated pressures. Fluid Phase Equilibria 2007;257:195-200.

20. Garaev V, Kleperis J, Pavlovica S, Vaivars G. Properties of the Nafion membrane impregnated with hydroxyl ammonium based ionic liquids. IOP Conf. Ser.: Mater. Sci. Eng. 2012;38:012064.

21. Ahfad-Hosseini HR, Bagheri H, Amidi S. Ionic liquid-assisted synthesis of celexocib using tris-(2hydroxyethyl)ammonium acetate as an 
efficient and reusable catalyst. IJPR 2017;16:158-64.

22. Anouti M, Caillon-Caravanier M, Le Floch C, Lemordant D. Alkylammonium-based protic ionic liquids part I: preparation and physicochemical characterization. J. Phys. Chem. B 2008;112:9406-11.

23. Pinkert A, Ang KL, Marsh KN, Pang $S$. Density, viscosity and electrical conductivity of protic alkanolammonium ionic liquids. Phys. Chem. Chem. Phys., 2011;13:5136-43.

24. Xu Y, Yao J, Wang C, Li H. Density, viscosity, and refractive index properties for the binary mixtures of nbutylammonium acetate ionic liquid + alkanols at several temperatures. J. Chem. Eng. Data 2012;57:298-308.

25. Kurnia KA, Wilfred $C D$, Murugesan $T$. Thermophysical properties of hydroxyl ammonium ionic liquids. J. Chem. Thermodynamics 2009;41:517-21.

26. Karadağ A, Destegül A. N-(2hydroxyethyl)-ethylenediamine-based ionic liquids: Synthesis, structural characterization, thermal, dielectric and catalytic properties. J. Mol. Liq. 2013;177:369-75.

27. Yuan XL, Zhang SJ, Lu XM. Hydroxyl ammonium ionic liquids: synthesis, properties, and solubility of $\mathrm{SO}_{2}$. J. Chem. Eng. Data 2007;52:596-99.

28. Gruzdev MS, Shmukler LE, Kudryakova NO, Kolker AM, Safonova LP. Synthesis and properties of triethanolamine-based salts with mineral and organic acids as protic ionic liquids. J. Mol. Liq. 2018;249:825-30.

29. Erdik E. Organik kimyada spektroskopik yöntemler (Turkish); Gazi Büro Kitabevi: Ankara, Turkey, 1993.
30. Fundamensky VS, Kochina TA, Kondratenko YA, Zolotarev AA, Vlasov YG, Ignatyev IS. Ionic liquids based on triethanolammonium salts of dicarboxylic acids (oxalic, malonic, succinic): crystal structure and cation-anion interaction. J. Mol. Liq. 2017;230:113-20.

31. Kondratenko Y, Kochina T, Fundamensky V, Ignatyev I, Panikorovskii T, Nyanikova G. Triethanolammonium salicylate-protic alkanolammonium ionic liquid. J. Mol. Liq. 2016;221:1218-24.

32. Gruzdev MS, Shmukler LE, Kudryakova NO, Kolker AM, Sergeeva YA, Safonova LP. Triethanolamine-based protic ionic liquids with various sulfonic acids: Synthesis and properties. J. Mol. Liq. 2017;242:838-44.

33. Deacon GB, Phillips RJ. Relationships between the carbon-oxygen stretching frequencies of carboxylato complexes and the type of carboxylate coordination. Coord. Chem. Rev. 1980;33:227-50.

34. Voronkov MG, Albanov AI, Aksamentova TN, Adamovich SN, Chipanina NN, Mirskov RG, Kochina TA, Vrazhnov DV, Litvinov MY. Tris(2hydroxyethyl)ammonium salts: 2,8,9Trihydroprotatranes. Russ. J. Gen. Chem. 2009;79:2339-46.

35. Kondratenkoa YA, Kochina TA, Fundamensky VS, Vlasov YG. Triethanolammonium salts of biologically active carboxylic acids. Russ. J. Gen. Chem. 2015;85:2710-14.

36. Gao L, Wan H, Han M, Guan G. Deep desulfurization of model oil by extraction with a low viscosity ionic liquid [BMIM]SCN. Petrol. Sci. Tech. 2014;32:1309-17.

37. DiGuilio RM, Lee RJ, Schaeffer ST, Brasher LL, Teja AS. Densities and viscosities of the ethanolamines. J. Chem. Eng. Data 1992;37:239-42. 